\title{
Geochemical characteristics of dissolved heavy metals in Zhujiang River, Southwest China: Spatial-temporal distribution, source, export flux estimation, and a water quality assessment
}

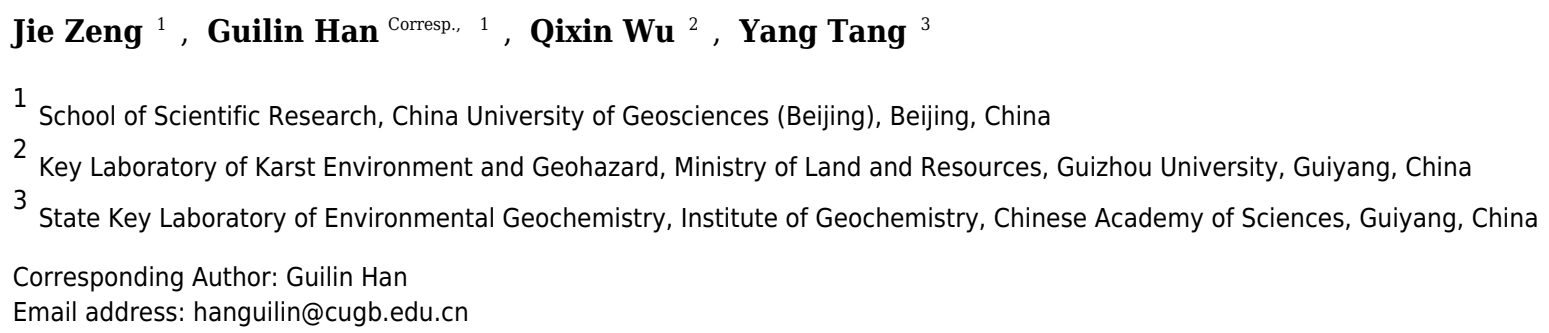

To investigate the sources and spatial-temporal distribution of dissolved heavy metals in river water, and to evaluate water quality, a total of 162 water samples are collected from 81 key sampling points in high and low flow seasons separately in the Zhujiang River, Southwest China. Ten dissolved heavy metals ( $\mathrm{V}, \mathrm{Cr}, \mathrm{Mn}, \mathrm{Co}, \mathrm{Ni}, \mathrm{Cu}, \mathrm{Mo}, \mathrm{Cd}, \mathrm{Ba}$, and $\mathrm{Pb}$ ) in the Zhujiang River water exhibit little variation at temporal scale, but vary with a significant spatial heterogeneity. Furthermore, different metals also present different variation trends along the main channel of the Zhujiang River. Our results suggest that $\mathrm{Ba}$ (14.72 $\mathrm{g} \mathrm{L} \mathrm{L}^{-1}$ in low flow season and $12.50 \mu \mathrm{g} \mathrm{L}^{-1}$ in high flow season) and $\mathrm{Cr}$ (6.85 $\mathrm{\mu g} \mathrm{L}^{-1}$ in low flow season and $7.52 \mathrm{\mu g} \mathrm{L}^{-1}$ in high flow season) are consistently the most abundant metals in both two sampling periods. According to the water quality (WQI values ranged from 1.3 to 43.9 ) and health risk assessment, metals investigated in Zhujiang River are below the hazard level (all hazard index $(\mathrm{HI})<1$ ). Application of statistical approaches, including correlation matrix and principal component analysis (PCA), identify three principal components that account for $61.74 \%$ of the total variance, the results conclude that the anthropogenic heavy metals $(\mathrm{V}, \mathrm{Cr}, \mathrm{Ni}$, and $\mathrm{Cu})$ are greatly impacted by dilution effect, and the heavy metals in Zhujiang River are mainly presented a natural sources signature from the perspective of entire basin. Moreover, our results reveal that the estimated export budget of several heavy metals including $\mathrm{V}\left(735.6 \mathrm{t} \mathrm{yr}^{-1}\right), \mathrm{Cr}\left(1561.1 \mathrm{t} \mathrm{yr}^{-1}\right.$ ), Ni (498.2 $\left.\mathrm{t} \mathrm{yr}^{-1}\right)$ and Mo (118.9 $\left.\mathrm{t} \mathrm{yr}^{-1}\right)$ to the ocean are higher than the world average. 
1

2 Geochemical characteristics of dissolved heavy metals in

3 Zhujiang River, Southwest China: Spatial-temporal distribution, 4 source, export flux estimation, and a water quality assessment

5

6

7

8 Jie Zeng ${ }^{1}$, Guilin $\mathrm{Han}^{1}$, Qixin $\mathrm{Wu}^{2}$, Yang Tang ${ }^{3}$

9

10

${ }^{1}$ School of Scientific Research, China University of Geosciences (Beijing), Beijing, China

$11{ }^{2}$ Key Laboratory of Karst Environment and Geohazard, Ministry of Land and Resources,

12 Guizhou University, Guiyang, China

$13{ }^{3}$ State Key Laboratory of Environmental Geochemistry, Institute of Geochemistry, Chinese

14 Academy of Sciences, Guiyang, China

15

16 Corresponding Author:

17 Guilin $\operatorname{Han}^{1}$

1829 Xueyuan Road, Haidian District, Beijing, 100083, China

19 Email address: hanguilin@cugb.edu.cn

20 


\section{Abstract}

22 To investigate the sources and spatial-temporal distribution of dissolved heavy metals in river

23

24

25

26

27

28

29

30

31

32

33

34

35

36

37

38

39

40

41

42

43

44

45

46

47

48

49

50

51

52

53

54

55

56

57

58

59

60

water, and to evaluate water quality, a total of 162 water samples are collected from 81 key sampling points in high and low flow seasons separately in the Zhujiang River, Southwest China. Ten dissolved heavy metals ( $\mathrm{V}, \mathrm{Cr}, \mathrm{Mn}, \mathrm{Co}, \mathrm{Ni}, \mathrm{Cu}, \mathrm{Mo}, \mathrm{Cd}, \mathrm{Ba}$, and $\mathrm{Pb}$ ) in the Zhujiang River water exhibit little variation at temporal scale, but vary with a significant spatial heterogeneity. Furthermore, different metals also present different variation trends along the main channel of the Zhujiang River. Our results suggest that Ba $\left(14.72 \mu \mathrm{g} \mathrm{L}^{-1}\right.$ in low flow season and $12.50 \mu \mathrm{g} \mathrm{L}^{-}$ 1 in high flow season) and $\operatorname{Cr}\left(6.85 \mu \mathrm{g} \mathrm{L} \mathrm{L}^{-1}\right.$ in low flow season and $7.52 \mu \mathrm{g} \mathrm{L}^{-1}$ in high flow season) are consistently the most abundant metals in both two sampling periods. According to the water quality (WQI values ranged from 1.3 to 43.9 ) and health risk assessment, metals investigated in Zhujiang River are below the hazard level (all hazard index $(\mathrm{HI})<1$ ).

Application of statistical approaches, including correlation matrix and principal component analysis (PCA), identify three principal components that account for $61.74 \%$ of the total variance, the results conclude that the anthropogenic heavy metals $(\mathrm{V}, \mathrm{Cr}, \mathrm{Ni}$, and $\mathrm{Cu})$ are greatly impacted by dilution effect, and the heavy metals in Zhujiang River are mainly presented a natural sources signature from the perspective of entire basin. Moreover, our results reveal that the estimated export budget of several heavy metals including $\mathrm{V}\left(735.6 \mathrm{t} \mathrm{yr}^{-1}\right), \mathrm{Cr}\left(1561.1 \mathrm{t} \mathrm{yr}^{-1}\right)$, $\mathrm{Ni}\left(498.2 \mathrm{t} \mathrm{yr}^{-1}\right)$ and Mo $\left(118.9 \mathrm{t} \mathrm{yr}^{-1}\right)$ to the ocean are higher than the world average.

\section{Introduction}

Along with the rapid development of social economy, due to the toxicity, persistence, and bioaccumulative nature, and its mostly negative impact on living organisms (Cameron et al. 2018; Farahat \& Linderholm 2015; Wilbers et al. 2014; Zaric et al. 2018), the contamination levels and environmental health effects of heavy metals aroused great public concern in the world. There are two main sources of heavy metals in the environment that significantly impact the biogeochemical cycling of heavy metals (Li \& Zhang 2010). One is natural sources, such as bedrock weathering, volcanism which are controlled by geology and lithology (Krishna et al. 2009; Li \& Zhang 2010); the other is anthropogenic activities, including mining, metal smelting and refining, energy producing and consuming, and waste incineration (Liu et al. 2013; Meng et al. 2016). We can identify heavy metal sources (natural and/or anthropogenic) by detecting their contents and distribution in the ecosystem.

Studies about environmental heavy metals has a long history (Zhang et al. 2009). These studies focused on various scales and different ecosystems, especially the fluvial system (Iwashita \& Shimamura 2003; Li \& Zhang 2010; Wang et al. 2017). Hitherto, numerous studies regarding heavy metal (or trace element) compositions and their effects on fluvial environment have been published in different countries (Gaillardet et al. 2014; Iwashita \& Shimamura 2003; Thévenot et al. 2007; Tripathee et al. 2016), including China (Li et al. 2011; Wang et al. 2017; Xiao et al. 2014; Zhang \& Zhou 1992). As the second largest river in China and the major river discharging into the South China Sea (Xu \& Han 2009), several researches have been performed to examine 
61 heavy metal composition of water and sediment in the Zhujiang River basin (Liu et al. 2017; Niu

62 et al. 2009; Ouyang et al. 2004; Zhang et al. 2018; Zhen et al. 2016). However, the spatial-

63 temporal distribution, source, health risk and export flux of dissolved heavy metals in Zhujiang

64 River from a whole basin perspective, have not been investigated systematically up to now.

65 This study is conducted as a survey on water geochemistry characteristics of dissolved heavy

66 metals in the Zhujiang River from a whole basin perspective. The aims are to: (1) analyze the

67 spatial-temporal distribution of ten dissolved heavy metals from the upper reaches to the lower

68 reaches, (2) explore the possible anthropogenic and/or natural sources of these heavy metals, (3)

69 define the water quality and the health risk of dissolved heavy metals, and (4) estimate the export

70 flux of dissolved heavy metals to South China Sea (SCS) roughly. The results would greatly help

71 manage and protect the water resources, provide water resources guarantee for socio-economic

72 development within the whole basin, and deliver some support for the assessment of heavy metal

73 input flux in the ocean.

74

75 Materials \& Methods

\section{Study area}

77 The Zhujiang River (Pearl River) basin is located in Southwest China $\left(21^{\circ} 31^{\prime}-26^{\circ} 49^{\prime} \mathrm{N}, 102^{\circ} 14^{\prime}-\right.$

$78115^{\circ} 53^{\prime} \mathrm{E}$ ), which is the largest river flowing into the SCS with a cover area of $4.5 \times 10^{5} \mathrm{~km}^{2}$ and

79 provides major water source for more than 30 million local population of southern China (Li et

80 al. 2019; Zhen et al. 2016). The Zhujiang River flows through Yunnan, Guizhou, Guangxi and

81 Guangdong province with the elevation decreases from northwest to southeast (Fig. 1). Five

82 principal reaches are defined along the main channel of Zhujiang River: the Nanpanjiang River

83 (NPR), the Hongshuihe River (HSR), the Qianjiang River (QJR), Xunjiang River (XUR) and

84 Xijiang River (XJR) (Fig. 1). Accordingly, the tributaries can also be divided into five parts. In

85 addition, the significant tributary (Beipanjiang River, BPR) located in the upstream area, is

86 discussed as an individual tributary here. The Zhujiang River basin is characterized by tropical to

87 subtropical monsoon climate, with a mean annual temperature varying from $14{ }^{\circ} \mathrm{C}$ to $22{ }^{\circ} \mathrm{C}$. The

88 average annual precipitation ranges from 1200 to $2200 \mathrm{~mm}$, where a majority of annual rainfall

89 ( $\sim 80 \%)$ occurs during the wet season (April to September) (Han et al. 2018; Li et al. 2019). The

90 Zhujiang River basin consists of various source rocks (Fig. 1). Permian and Triassic carbonate

91 rocks with intercalated coal-bearing formations are extensively distributed in the mid-upper river

92 reaches with an area account for $44 \%$ of the whole basin area. Jurassic detrital sedimentary

93 rocks are distributed sporadically in the river source area and are intercalated fragmentarily in the

94 middle and the lower river reaches. The mid-lower reaches consist mostly of Precambrian

95 metamorphic rocks and magmatic rocks (Han et al. 2018; Li et al. 2019; Li et al. 2000). There

96 are 24 large reservoirs/dams (with capacity exceed $10^{8} \mathrm{~m}^{3}$ ) and 212 medium reservoirs/dams

97 (capacity from $10^{7}$ to $10^{8} \mathrm{~m}^{3}$ ) located in the mid-lower reaches of the Zhujiang River (Han et al.

98 2018).

99

100 Sample Collection and Analysis 
101 Two sampling campaigns from 81 sites represent varying hydrologic period settings throughout

102

103

104

105

106

107

108

109

110

111

112

113

114

115

116

117

118

119

120

121

122

123

124

125

126

127

128

129

130

131

132

133

134

135

136

137

138

139 the Zhujiang River during July 2014 (high flow season) and in January 2015 (low flow season) are conducted (Fig. 1). And 9, 3, 3, 5, and 5 sites are located in NPR, HSR, QJR, XUR, and XJR, while 5, 7, 7, 7, 11, and 19 sites are located in the corresponding tributaries of NPR, HSR, QJR, XUR, XJR and BPR. More detailed information on sampling points could be found in Table S1. Thus, a total of 162 river water samples are collected at a depth of approximate $15 \mathrm{~cm}$. After collection, the water samples are immediately filtered in the field through $0.22 \mu \mathrm{m}$ Millipore membrane filters. Water samples for heavy metals analysis are acidified to $\mathrm{pH}<2$ with ultrapurified $\mathrm{HNO}_{3}$ and then sealed in a pre-cleaned polyethylene bottles and stored in a dark refrigerator before analysis. The $\mathrm{pH}$, electrical conductivity (EC), dissolved oxygen (DO) and temperature $(\mathrm{T})$ are immediately measured by a multi-parameter meter (MultiLine 3320, WTW, Germany) in the field. Ten heavy metals, including V, Cr, Mn, Co, Ni, Cu, Mo, Cd, Ba, and Pb are analyzed by using inductively coupled plasma-mass spectrometry (ICP-MS, Elan DRC-e, Perkin Elmer, US) at the Institute of Geographic Sciences and Natural Resources Research, Chinese Academy of Sciences. Standard reference materials (GSB 04-1767-2004) are used to perform the method validation and quality control. All the samples and standards are analyzed in batches with a procedural blank. Recovery percentage ranges between $90.0 \%$ and $110.4 \%$.

Relative standard deviations for heavy metals are $\sim \pm 5 \%$.

\section{Statistical analysis and assessment methods}

\section{Multivariate Analysis}

Statistical approaches, including correlation matrix and principal component analysis (PCA) are used to analyze the dataset to acquire descriptive statistics and explore the possible sources of the selected dissolved heavy metals. PCA is the most common multivariate statistical method to explore associations and origins of heavy metals (Loska \& Wiechuła 2003). PCA is generally via reducing the dimensionality of the dataset to several influencing factors while trying to preserve the relationships presented in the original data, a fact which commonly occurs in hydrochemistry (Li et al. 2011; Wang et al. 2017). The suitability of the dataset for factor analysis is checked by Kaiser-Meyer-Olkin (KMO) and Bartlett's sphericity test $(\mathrm{p}<0.001)$ (Li et al. 2011). Before performing the PCA, each variable is first normalized to avoid numerical ranges of the original variables by z-scale transformation (Chen et al. 2007; Wang et al. 2017). Then, PCA with varimax rotation is run. Only components with eigenvalues exceeding 1 after rotation are extracted. All of the data processes are performed using the Microsoft Office 2010 and the statistical software package SPSS 21.0 for Windows.

\section{Water quality index}

The water quality index (WQI), a powerful tool that reflects the integrated influence of different water quality variables (heavy metals in this study), present a comprehensive picture of river water quality (Wang et al. 2017; Xiao et al. 2014). V is excluded in the WQI calculations due to the lack of official drinking water standard. The WQI is calculated as follows:

$\mathrm{WQI}=\sum\left[\mathrm{w}_{\mathrm{i}} \times\left(\mathrm{C}_{\mathrm{i}} / \mathrm{S}_{\mathrm{i}}\right)\right] \times 100$ 
140 Where $\mathrm{w}_{\mathrm{i}}$ is the weight of each heavy metal $\mathrm{i}$ and represents the relative importance of different

141

142

143

144

145

146

147

148

149

150

151

152

153

154

155

156

157

158

159

160

161

162

163

164

165

166

167

168

169

170

171

172

173

174

\section{Results}

176

177

178

$\mathrm{HQ}=\mathrm{ADD} / \mathrm{RfD}$

$\mathrm{HI}=\sum \mathrm{HQs}$ water quality variables in the overall quality of water for drinking, and is depend on the foundation of the eigenvalues for each principal component and factor loading for each parameter from the PCA results. $\mathrm{C}_{\mathrm{i}}$ is the heavy metal concentration in water samples $\left(\mu \mathrm{g} \mathrm{L}^{-1}\right)$, and $\mathrm{S}_{\mathrm{i}}$ is the Chinese Drinking Water Guideline (GB 5749-2006) for each heavy metal ( $\left.\mu \mathrm{g} \mathrm{L}^{-1}\right)$. The obtained WQI values can be defined as five classifications: excellent water quality $(0 \leq \mathrm{WQI}<50)$, good water quality $(50 \leq \mathrm{WQI}<100)$, poor water quality $(100 \leq \mathrm{WQI}<200)$, very poor water quality $(200 \leq \mathrm{WQI}<300)$, and WQI $>300$ represents water that is unsuitable for drinking (Meng et al. 2016; Wang et al. 2017).

\section{Health risk assessment}

To quantitatively evaluate health risks, the Hazard quotient (HQ) and hazard index (HI), which are suggested by the US EPA and have been commonly used for the river water risk assessments in previous studies (Meng et al. 2016; Wang et al. 2017), are calculated in this study. Ingestion and dermal absorption are two main pathways potentially expose to heavy metals in water for humans beings (De Miguel et al. 2007). HQ is the ratio between exposure via each pathways and the reference dose (RfD). HI is the sum of the HQs for each heavy metal from both the ingestion and dermal pathways to assess the total potential non-carcinogenic risk of individual metals. If the HQ or HI is exceeds 1, non-carcinogenic risk/adverse effects on human health are a concern and the further study is necessary. In contrast, there are no deleterious effects when $\mathrm{HQ} / \mathrm{HI}$ is smaller than one (Wang et al. 2017). The HQ and HI are calculated as follows:

$\mathrm{ADD}_{\text {ingestion }}=\left(\mathrm{C}_{\mathrm{w}} \times \mathrm{IR} \times \mathrm{EF} \times \mathrm{ED}\right) /(\mathrm{BW} \times \mathrm{AT})$

$\mathrm{ADD}_{\text {dermal }}=\left(\mathrm{C}_{\mathrm{w}} \times \mathrm{SA} \times \mathrm{K}_{\mathrm{p}} \times \mathrm{ET} \times \mathrm{EF} \times \mathrm{ED} \times 10^{-3}\right) /(\mathrm{BW} \times \mathrm{AT})$

$\mathrm{RfD}_{\text {dermal }}=\mathrm{RfD} \times \mathrm{ABS}_{\mathrm{GI}}$

where $\mathrm{ADD}_{\text {ingestion }}$ and $\mathrm{ADD}_{\text {dermal }}$ are the average daily doses by ingestion and dermal absorption $\left(\mu \mathrm{g} \mathrm{kg}^{-1}\right.$ day $\left.^{-1}\right)$, respectively; $\mathrm{C}_{\mathrm{w}}$ is the heavy metal concentration in water samples $\left(\mu \mathrm{g} \mathrm{L}^{-1}\right)$; BW is the average body weight for adults and children $(\mathrm{kg})$; IR is the ingestion rate $\left(\mathrm{L} \mathrm{day}^{-1}\right)$; EF is the exposure frequency (days $\mathrm{yr}^{-1}$ ); ED is the exposure duration (years); AT is the average time (days); SA is area the exposed skin $\left(\mathrm{cm}^{2}\right)$; ET is exposure time $\left(\mathrm{h} \mathrm{day}^{-1}\right) ; \mathrm{K}_{\mathrm{p}}$ is the dermal permeability coefficient in water of individual metals $\left(\mathrm{cm} \mathrm{h}^{-1}\right)$; RfD is the corresponding reference dose $\left(\mu \mathrm{g} \mathrm{kg}^{-1} \mathrm{day}^{-1}\right)$; and $\mathrm{ABS}_{\mathrm{GI}}$ is the gastrointestinal absorption factor (dimensionless) (Wang et al. 2017; Wu et al. 2009). The corresponding parameters are obtained from the US EPA (2004).

\section{Kolmogorov-Smirnov test of data}

Kolmogorov-Smirnov test, as a non-parametric test, is generally used to data analysis when the sample size is small. Thus, the normal distribution test of our data in this study is using 
179 Kolmogorov-Smirnov (K-S) statistics (Table 1). The test results show that the V, Cr, $\mathrm{pH}, \mathrm{EC}$, 180 and DO are normally distributed during low flow season, and the $\mathrm{V}, \mathrm{Cr}, \mathrm{Mo}, \mathrm{pH}, \mathrm{EC}, \mathrm{DO}$, and 181 temperature approach a normal distribution during high flow season. The K-S test results and 182 large standard deviation values for the remaining dissolved heavy metals indicatives of that the average concentration might have been seriously impacted by the outliers, which related to water samples with tremendously high or low values. Thus, the median concentrations instead of arithmetic means for these heavy metals are used in our calculations. In addition, based on the K$\mathrm{S}$ test results, the median concentrations of all studied dissolved heavy metals are used for comparisons, although the limited values in the guidelines are widely given as arithmetic means.

The statistics values of water quality parameters $(\mathrm{pH}, \mathrm{EC}, \mathrm{DO}$, and $\mathrm{T})$ in the water samples from the Zhujiang River are given in Table 1. The average $\mathrm{pH}$ values are 7.9 (7.0 to 8.8) in low flow season and 7.7 (6.4 to 8.4) in high flow season, presenting slightly alkaline characteristics. The EC values of water samples vary from 76.0 to $602.0 \mu \mathrm{S} \mathrm{cm}^{-1}$, with an average of $354.6 \mu \mathrm{S} \mathrm{cm}^{-1}$ in low flow season, and range from 90.0 to $533.0 \mu \mathrm{S} \mathrm{cm}^{-1}$, with an average of $307.7 \mu \mathrm{S} \mathrm{cm}^{-1}$ in high flow season, respectively. The average dissolved oxygen values are $8.7 \mathrm{mg} \mathrm{L}^{-1}$ in low flow season and $7.5 \mathrm{mg} \mathrm{L}^{-1}$ in high flow season, respectively. Overall, the $\mathrm{pH}, \mathrm{EC}$, and DO values are consistently higher in low flow season than in high flow season. However, since the river water is continuously heated by sunlight, the water temperatures in high flow season $\left(26.5^{\circ} \mathrm{C}\right.$, with a range of 18.0 to $\left.36.0^{\circ} \mathrm{C}\right)$ are higher than in low flow season $\left(16.4^{\circ} \mathrm{C}\right.$, with a range of 10.2 to $\left.26.6^{\circ} \mathrm{C}\right)$. The variations in water temperature during the same season are primary caused by the

200

201 differences of sampling time of day, that is, the water temperatures in morning are generally lower than noon.

202

203

204

205

206

\section{Heavy metals content}

The descriptive statistics of studied dissolved heavy metals in Zhujiang River are presented in Table 1. The concentration (median) of ten heavy metals in low flow season is decreased in the following sequence, $\mathrm{Ba}\left(14.72 \mu \mathrm{g} \mathrm{L}^{-1}\right), \mathrm{Cr}\left(6.85 \mu \mathrm{g} \mathrm{L}^{-1}\right), \mathrm{Ni}\left(2.39 \mu \mathrm{g} \mathrm{L}^{-1}\right), \mathrm{V}\left(2.13 \mu \mathrm{g} \mathrm{L}^{-1}\right), \mathrm{Cu}$ $\left(0.90 \mu \mathrm{g} \mathrm{L}^{-1}\right)$, Mo $(0.63 \mu \mathrm{g} \mathrm{L}-1), \mathrm{Mn}\left(0.45 \mu \mathrm{g} \mathrm{L}^{-1}\right), \mathrm{Co}\left(0.11 \mu \mathrm{g} \mathrm{L}^{-1}\right), \mathrm{Pb}\left(0.06 \mu \mathrm{g} \mathrm{L}^{-1}\right), \mathrm{Cd}(0.04 \mu \mathrm{g}$ $\left.\mathrm{L}^{-1}\right)$. Whereas the declined sequence of these heavy metals in the high flow season is as follows, $\mathrm{Ba}\left(12.50 \mu \mathrm{g} \mathrm{L}^{-1}\right), \mathrm{Cr}\left(7.52 \mu \mathrm{g} \mathrm{L}^{-1}\right), \mathrm{V}\left(2.59 \mu \mathrm{g} \mathrm{L}^{-1}\right), \mathrm{Ni}\left(2.08 \mu \mathrm{g} \mathrm{L}^{-1}\right), \mathrm{Cu}\left(0.77 \mu \mathrm{g} \mathrm{L}^{-1}\right)$, Mo $(0.44$ $\left.\mu \mathrm{g} \mathrm{L}^{-1}\right), \mathrm{Mn}\left(0.40 \mu \mathrm{g} \mathrm{L}^{-1}\right), \mathrm{Co}\left(0.11 \mu \mathrm{g} \mathrm{L}^{-1}\right), \mathrm{Pb}\left(0.04 \mu \mathrm{g} \mathrm{L}^{-1}\right), \mathrm{Cd}\left(0.03 \mu \mathrm{g} \mathrm{L}^{-1}\right) . \mathrm{Ba}$ and $\mathrm{Cr}$ are consistently the most abundant metals in both two sampling periods.

\section{Spatial distribution of heavy metals}

\section{Distribution of heavy metals along the main stream}

213 The distribution for each individual heavy metal along the main stream exhibits an extensive

214 variation (Fig. 2). In the main stream water body, V concentration present a gradually increasing

215 trend from upstream to downstream overall, with a higher concentration in the middle of the

216 NPR reach. In contrast, $\mathrm{Cr}$ and Co exhibits a slowly decreasing trend from upstream to

217 downstream, but perform a higher concentration in the middle of the NPR reach. $\mathrm{Cu}$

218 concentration is maintained at a low level, and present a very high value for only a few sampling 
219 points (10 times more than other points). Mo concentration gradually increase in the NPR reach

220

221

222

223

224

225

226

227

228

229

230

231

232

233

234

235

236

237

238

239

240

241

242

243

244

245

246

247

248

249

250

251

252

253

254

255

256

257

and began to decline after entering the HSR reach, until the QJR reach become stable. There is a great fluctuation of $\mathrm{Ba}$ concentration in the upstream reach, with the highest concentration in the middle of NPR reach, and subsequently decrease to the lowest value in QJR reach, and then exhibit a slowly rising trend in the downstream reach (XUR and XJR). Pb concentration is fluctuated in a relatively wider range in NPR and HSR reach, and tended to stabilize in in QJR to XJR reach. $\mathrm{Mn}, \mathrm{Ni}$, and $\mathrm{Cd}$ display obviously fluctuation along the main stream, with no significant pattern of distribution. Moreover, there are 24 large reservoirs/dams located in the mid-lower reaches along the main channel of the Zhujiang River (Han et al. 2018). The suspended particles, gravels that absorbed heavy metals would be separated from the water physically as water flow slows down in the reservoirs ( $\mathrm{Li}$ et al. 2008), which could be considered as a potentially factor for the spatial variation of the dissolved heavy metals, and may result in the variation of concentration of some dissolved heavy metals in the mid-lower reaches.

\section{Distribution of heavy metals in tributaries}

The distribution for each individual heavy metal in tributaries of different river reaches is exhibited in Fig. 3. Compare the median concentrations of heavy metals in tributaries, the $\mathrm{V}$ concentration is lower in the upstream tributaries than the downstream tributaries (except T$\mathrm{NPR}$ ), while $\mathrm{Cr}$ and $\mathrm{Co}$ are higher in the upstream tributaries than the downstream tributaries. It is consistent with the $\mathrm{V}, \mathrm{Cr}$, and Co concentration distribution in the main stream. Inconsistent with the main stream, $\mathrm{Ni}$ concentration present a similar distribution pattern to $\mathrm{Cr}$ and $\mathrm{Co}$ in the tributaries of each reaches, which is higher in the upstream tributaries than the downstream tributaries. In addition, Mn concentration shows that the upstream tributaries are lower than the downstream tributaries, and the fluctuated range is obviously increased in the tributaries of the downstream region. The remaining heavy metals $(\mathrm{Cu}, \mathrm{Mo}, \mathrm{Ba}, \mathrm{Pb}$, and $\mathrm{Cd})$ exhibit an extensive variation in the tributaries of each reaches, with no significant pattern, but it should be noted that the fluctuation of several heavy metals $(\mathrm{Mo}, \mathrm{Pb}$, and $\mathrm{Cd})$ in the downstream tributaries are relatively more intense than in the upstream tributaries.

\section{Seasonal variation of heavy metals}

On the seasonal scale, only V concentration exhibit a significant seasonal variation in both of main stream and tributaries, which is consistently higher in high flow season than in low flow season (Figs. 2 and 3). Along the main stream, Cr concentration is also higher in high flow season than in low flow season (except for a few points in the midstream and downstream) (Fig. 2). In contrast, $\mathrm{Co}, \mathrm{Mo}, \mathrm{Ba}, \mathrm{Pb}$, and $\mathrm{Cd}$ concentrations are higher in low flow season than in high flow season for most of sampling sites. However, there are no significant patterns of the seasonal variation of $\mathrm{Mn}, \mathrm{Ni}$, and $\mathrm{Cu}$ concentration along the main stream (Fig. 2). For the tributaries, the seasonal variation patterns of the concentration of all heavy metals (except $\mathrm{V}$ ) are not obvious (Fig. 3). Generally, the concentration of dissolved heavy metals would be reduced by the dilution effect during the high flow season, which is controlled by river flow (Li \& Zhang 2010; Olías et al. 2004).Therefore, the $\mathrm{Co}, \mathrm{Mo}, \mathrm{Ba}, \mathrm{Pb}$, and $\mathrm{Cd}$ concentrations are higher in low flow season 
258 than in high flow season at most of sampling sites along the main stream (Fig. 2) may be mainly 259 affected by dilution effect.

260 Discussion

\section{Concentrations of heavy metals in river water}

262 The concentration of dissolved heavy metals are compared with the limited values for drinking 263 water guidelines of China (2006), WHO (2006), US EPA (2003) (Table 1) and the surface water 264 standard of China (2002) (Table S2). All the concentrations (median) of heavy metals are within

265

266

267

268

269

270

271

272

273

274

275

276

277

278

279

280

281

282

283

284

285

286

287

288

289

290

291

292

293

294

295

296

297 the limited values for three drinking water guidelines (except $\mathrm{V}$, without limited values in any guidelines), and the $\mathrm{Cr}, \mathrm{Cu}, \mathrm{Cd}$, and $\mathrm{Pb}$ concentrations (median) are of Grade I of surface water standard, which indicate that pretty clean water without heavy metals pollution in Zhujiang River overall. In addition, the maximum concentrations of $\mathrm{Mn}$ and $\mathrm{Ni}$ are lower than the limited values of WHO drinking water guideline but are approximately two times higher than the Chinese drinking water guideline, and the maximum concentrations of Mo in low flow season is higher than the Chinese drinking water guideline. These heavy metals with maximum concentrations exceed guideline values can be defined as pollutants, which could attribute to the relatively high anthropogenic input from local sampling sites. For instance, although the $\mathrm{Cu}$ concentrations at all sampling sites are well below the guideline values, but the $\mathrm{Cu}$ concentrations at the two sampling sites (site 1 and 2, close to the Zhanyi county) of NPR reach along the main stream are significantly higher than that of other sites (Fig. 2), which shows the significant impact of the anthropogenic input from the Zhanyi county (eg. urban sewage discharge). Compare with the background values of the source area of the Yangtze River (Table 1) (Zhang \& Zhou 1992), the concentrations (median) of $\mathrm{V}, \mathrm{Cr}, \mathrm{Ni}, \mathrm{Cu}$, and $\mathrm{Cd}$ in water within the Zhujiang River are significantly elevated, while $\mathrm{Mn}, \mathrm{Co}, \mathrm{Mo}$, and $\mathrm{Pb}$ are lower than the source area of the Yangtze River. In low flow season, $\mathrm{V}, \mathrm{Cr}, \mathrm{Ni}, \mathrm{Cu}$, and $\mathrm{Cd}$ are 9.2, 26.4, 13.3, 1.4, and 2.9 times higher than the river water background of the Yangtze River. In high flow season, $\mathrm{V}, \mathrm{Cr}, \mathrm{Ni}, \mathrm{Cu}$, and $\mathrm{Cd}$ are 11.2, 28.9, 11.5, 1.2, and 2.2 times higher than the background values.

On a global scale, we compare our river samples with data of other rivers both from China and other counties or regions worldwide (Gaillardet et al. 2014) (Table S3). V, Cr, and Ni, concentrations of our study are higher than those worldwide rivers (except Seine River, a river severely affected by human activities in France). The Co and Mo concentrations are comparable to the worldwide rivers average concentration, but the Co concentration is much higher than that in Yellow River of China. Moreover, the $\mathrm{Cu}, \mathrm{Cd}, \mathrm{Ba}$, and $\mathrm{Pb}$ concentrations are slightly lower than the world river average, while the Mn concentration is much lower than world river average.

\section{Statistical analysis and source identification of heavy metals Correlation analysis}

The correlation matrix is useful for exploring associations between variables via giving the overall coherence of the dataset (Chen et al. 2007). A correlation matrix is employed to distinguish correlations between the 10 heavy metals in the two sampling periods (Table 2).

Strong positive correlations $(\mathrm{p}<0.01)$ are only observed between $\mathrm{Co}$ and $\mathrm{Mn}(0.591), \mathrm{Pb}$ and $\mathrm{Mn}$ 
298 (0.673), $\mathrm{Cu}$ and $\mathrm{Ni}(0.650)$ in low flow season, and the positive correlations between $\mathrm{Pb}$ and $\mathrm{Co}$ $299(0.284)$ are also obtained in same season. In contrast, the strong positive correlations $(\mathrm{p}<0.01)$ 300 between $\mathrm{Co}$ and $\mathrm{Cr}(0.477), \mathrm{Co}$ and $\mathrm{Mn}(0.520), \mathrm{Cu}$ and $\mathrm{Ni}(0.538)$ are observed in high flow 301 season (Table 2). The heavy metals with high correlation coefficients in the water body could 302 have similar sources, migration processes and hydrochemical behavior in the study area (Wang 303 et al. 2017). Therefore, $\mathrm{Mn}, \mathrm{Co}$, and $\mathrm{Pb}$ could origin from similar sources and input to the water 304 body after similar chemical processes in low flow season, while $\mathrm{Co}$ and $\mathrm{Cr}$ could have similar 305 sources in high flow season. And the consistently strong positive correlations between $\mathrm{Cu}$ and $\mathrm{Ni}$ 306 in the two periods indicate that the origins and migration of these two metals are remarkably 307 similar. However, the weak positive correlations, different degrees of negative correlation or 308 without significant correlation between each pair of remaining heavy metals are also observed 309 (Table 2), which indicate that there is strong spatial and temporal heterogeneity of the sources of 310 these heavy metals.

\section{Principal component analysis}

312 PCA is carried out for heavy metal concentrations along the main channel of Zhujiang River to explore metal associations and their possible origins, three principal components (PC, eigenvalues $>1$ ) are extracted in our study, including the eigenvalues, variance and communalities, are listed in Table 3. The PC 1 explain $22.59 \%$ of total variance and predominantly include $\mathrm{V}, \mathrm{Cr}, \mathrm{Co}$, and $\mathrm{Ba}$; the $\mathrm{PC} 2$ explain $20.91 \%$ of total variance with significant loadings of $\mathrm{Mn}, \mathrm{Ni}$, and $\mathrm{Cu}$; the $\mathrm{PC} 3$ explain $18.23 \%$ of variance which is mainly contributed by $\mathrm{Mo}, \mathrm{Cd}$, and $\mathrm{Pb}$. These three PCs totally account for $61.74 \%$ of the total variance, and are presented in a three-dimensional space, as shown in Fig. 4. Our results of overall PCs loadings $(61.74 \%)$ are relatively lower than other studies, i.e., PCs loadings for 14 heavy metals and 13 metals are $86.36 \%$ and $79.31 \%$ (Meng et al. 2016; Wang et al. 2017), respectively. Previous studies have performed PCA for heavy metals in numerous of river system and attained different results (Li \& Zhang 2010; Wang et al. 2017; Xiao et al. 2014), we ascribe these variations to different fluvial environments (i.e., watershed area, discharge, and land use) and different water variables. In general, the $\mathrm{Cr}, \mathrm{Co}, \mathrm{Ba}$, and $\mathrm{Mo}$ are from natural sources of rock weathering and subsequent pedogenesis (Li \& Zhang 2010), and V is greatly impacted by anthropogenic activities such as mining and agricultural processes ( $\mathrm{Li}$ et al. 2008). Considering the high concentrations of $\mathrm{V}$ and $\mathrm{Cr}$ (much higher than the background value of the Yangtze River, Table 1), and the most of elements in PC1 (V, Cr, Co, Ba) are lithophile elements (Krishna et al. 2009), hence we attribute this component (PC 1) to the mixed sources of geologic and anthropogenic origins in the basin. The high concentrations of $\mathrm{Cu}$ and $\mathrm{Ni}$ in PC 2 are observed in Zhujiang River (compared to the background value), and $\mathrm{Cu}$ is used as markers of metal industries (Li \& Zhang 2010), while $\mathrm{Ni}$ is the common pollutant discharge from the electroplating industry and metal smelting. In combination with the negative loadings or weak positive loadings of $\mathrm{Cu}$ and $\mathrm{Ni}$ in $\mathrm{PC} 1$ and the positive correlations between $\mathrm{Cu}$ and $\mathrm{Ni}$ (Table 2), the PC 2 with positive loadings on $\mathrm{Cu}(0.89)$ and $\mathrm{Ni}(0.67)$ can be attribute to anthropogenic origins in the basin. In addition, although $\mathrm{Cd}$ and 
$338 \mathrm{~Pb}$ are major pollutants emitted from industrial wastes and automobile exhausts (Krishna et al.

339

340

341

342

343

344

345

346

347

348

349

350

351

352

353

354

355

356

357

358

359

360

361

362

363

364

365

366

367

368

369

370

371

372

373

374

375

376

377

2009; Pekey et al. 2004), but the concentrations of these two heavy metals and Mo are not high

in the Zhujiang River, even lower than the background value of the Yangtze River. Therefore, $\mathrm{Cd}, \mathrm{Pb}$ and Mo in PC 3 may be greatly contributed by natural sources.

In spite of the results of PCA suggest that some heavy metals $(\mathrm{V}, \mathrm{Cr}, \mathrm{Ni}$, and $\mathrm{Cu})$ are possibly caused by the anthropogenic inputs or the mixed sources of geologic and anthropogenic origins. However, the rest of heavy metals with low concentrations below the background value are controlled by the natural sources or assuaged by the varying landscape setting and the relatively weak rock weathering processes. Compared to the polluted rivers such as Huaihe River $(\mathrm{Cu}$ (28.61 $\left.\mu \mathrm{g} \mathrm{L}{ }^{-1}\right), \mathrm{Pb}(97.83 \mu \mathrm{g} \mathrm{L}-1), \mathrm{Ni}\left(16.00 \mu \mathrm{g} \mathrm{L}^{-1}\right), \mathrm{Cr}\left(19.7 \mu \mathrm{g} \mathrm{L}^{-1}\right)$ ) (Wang et al. 2017), the concentration level of heavy metals in the Zhujiang River are fairly low (Table 1). Therefore, we hold that dilution has a great impact on the anthropogenic heavy metals $(\mathrm{V}, \mathrm{Cr}, \mathrm{Ni}$, and $\mathrm{Cu})$ within such a large catchment area. The dissolved heavy metals in Zhujiang River are mainly presented a natural sources signature.

\section{Water quality and health risk in river water}

The allowable limit of $\mathrm{pH}$ for drinking water ranges from 6.5 to 8.5 (Table 1). The $\mathrm{pH}$ values in $95.7 \%$ of the water samples are conformed to this regulation in our study. Based on PCA results, the weights of each heavy metal $\left(\mathrm{w}_{\mathrm{i}}\right)$ are obtained and summarized in Table 4 . Therefore, the calculated WQI values using Eq. (1) are shown in Table S1. In this study, the WQI values ranges from 1.5 to 43.9 and 1.3 to 27.9 for water samples during the low and high flow season, respectively. The calculated WQI values based on the median concentrations of heavy metals in the two seasons are 3.3 and 3.2. Only two sites (site 61 and 74 ) are evaluated as a relatively high WQI value (43.9 and 33.5) in low flow season. All the water samples can be defined as excellent water quality (the calculated WQI values are less than 50), indicative of that the natural water within the Zhujiang River drainage area is suitable for drinking, at least from the perspective of heavy metal pollution.

The HQ and HI values for the heavy metals via ingestion and dermal pathways for adults and children are calculated with the median concentrations based on Eq. (2) to (6), respectively. As shown in Table 5, for both adults and children, the $\mathrm{HQ}_{\text {ingestion, }} \mathrm{HQ}_{\text {dermal }}$ and $\mathrm{HIs}$ for all heavy metals are smaller than 1, indicate that the metals investigated in the Zhujiang River basin are all below the hazard level (through oral ingestion and dermal absorption), and the health effects of these heavy metals are very limited. It should be noted that the $\mathrm{HQ}_{\text {ingestion }}$ and $\mathrm{HQ}_{\text {dermal }}$ values for children are relatively higher than adults, suggest that children are more risky under the heavy metals exposure. Moreover, at some sampling points with the maximal heavy metal concentrations, the $\mathrm{HI}$ of $\mathrm{Mo}$ ( 0.539 and 0.826 for adults and children, respectively; site 68 ) and Mn (0.573 for children; site 74) are relatively close to 1 in low flow season. Consequently, we conclude that Mo and Mn could be a potential non-carcinogenic risk to human health in some sites, especially in low flow season.

In spite of the risk assessment indicate that there are no most widespread pollutants in the Zhujiang River basin, similar to the results from WQI. Several studies have reported the adverse 
378 effects of heavy metals, Such as the toxicity of $\mathrm{Pb}$ on the nervous and endocrine systems in the 379 human body (Fang et al. 2014); the adverse effects of $\mathrm{Cd}$ in the renal system and bone injuries 380 (Bertin \& Averbeck 2006); the effects of Mo on reproduction and foetal development (Vyskocil $381 \&$ Viau 1999). Therefore, special measures should be taken to prevent the input of heavy metals

382

383

384

385

386

387

388

389

390

391

392

393

394

395

396

397

398

399

400

401

402

403

404

405

406

407

408

409

410

411

412

413

414

415

416 into the Zhujiang River for the protection of the excellent water quality, and to provide water resources guarantee for socio-economic development within the whole basin.

\section{Heavy metals export budget of Zhujiang River to the South China Sea}

By taking the concentrations of the dissolved heavy metals in low flow season (October to March of the following year) and high flow season (April to September), and the discharge at the mouth of the Zhujiang River of the two seasons (River and Sediment Bulletin of China, http://www.mwr.gov.cn/sj/tigb/zghlnsgb/), river fluxes of individual of heavy metal to the South China Sea are estimated that range from $8.6(\mathrm{~Pb})$ to $3713.5(\mathrm{Ba})$ tons during the hydrologic year 2014 to 2015 (Table 6). It should be noted that $80 \%, 76 \%, 25 \%, 71 \%, 58 \%, 63 \%, 70 \%, 80 \%$, $74 \%$, and $63 \%$ of the $\mathrm{V}, \mathrm{Cr}, \mathrm{Mn}, \mathrm{Co}, \mathrm{Ni}, \mathrm{Cu}, \mathrm{Mo}, \mathrm{Cd}, \mathrm{Ba}$, and $\mathrm{Pb}$ flux produced in the high flow season, which is mainly controlled by the high discharge $\left(1.72 \times 10^{11} \mathrm{~m}^{3}\right.$, account for $74.1 \%$ discharge of whole hydrologic year) in this season. Table 6 also presented the estimated heavy metal flux of Zhujiang River in 2002, which is calculated by the heavy metal concentrations from previous study (Ouyang et al. 2004) and the discharge in the corresponding year. Most of the estimated heavy metal fluxes are decreased from 2002 to 2015 for the Zhujiang River (except V) (Table 6). Thus, the environmental policy in last decade might reduce the anthropogenic heavy metal inputs to the Zhujiang River in China. Compared with literature values (Gaillardet et al. 2014), the proportion of the annual estimated export flux of $\mathrm{V}, \mathrm{Cr}, \mathrm{Mn}, \mathrm{Co}, \mathrm{Ni}, \mathrm{Cu}, \mathrm{Mo}, \mathrm{Cd}$, $\mathrm{Ba}$, and $\mathrm{Pb}$ in Zhujiang River in the global rivers are $2.7 \%, 6.0 \%, 0.01 \%, 0.4 \%, 1.7 \%, 0.3 \%$, $0.7 \%, 0.4 \%, 0.4 \%$, and $0.3 \%$, respectively. Based on the annual river discharge of $3.74 \times 10^{13} \mathrm{~m}^{3}$ $\mathrm{yr}^{-1}$ for global rivers (Xu \& Han 2009), the annual discharge of the Zhujiang River in the total annual discharge of the world's rivers is estimated as $0.6 \%$. The proportion of $\mathrm{V}, \mathrm{Cr}, \mathrm{Ni}$, and $\mathrm{Mo}$ export fluxes of Zhujiang River in global rivers exceeds $0.6 \%$, which suggests that the contribution of $\mathrm{V}, \mathrm{Cr}, \mathrm{Ni}$, and Mo of Zhujiang River export to the marine system are higher than the world average level.

In this study, the concentrations of heavy metals in the estuary of the Zhujiang River present different degrees in the two seasons (Fig. 2). Given that most of the heavy metals export occurred in the rainy season, and there may be large uncertainty in estimation of heavy metal fluxes due to the limited temporal sampling interval in the Zhujiang River, particularly in the high flow season with a conspicuous variation of heavy metal concentrations after a storm event, our data from one sole sampling campaign may be incomplete. Therefore, high-frequency sampling (monthly, weekly even daily sampling) is necessary and is vital significance to precisely quantify heavy metal annual budget from the terrestrial rivers to the ocean.

\section{Conclusions}


417 In conclusion, the dissolved heavy metals in the Zhujiang River water exhibit little variation at 418 temporal scale, but vary with a significant spatial heterogeneity. Ba and $\mathrm{Cr}$ are consistently the 419 most abundant metals in both two sampling periods. All the concentrations of heavy metals are 420 within the limited values for Chinese drinking water guidelines except for few specific sites, and 421 the water quality and health risk assessment also reveal that the metals investigated in Zhujiang 422 River are below the hazard level with a low risk. PCA results conclude that the dissolved heavy 423 metals in Zhujiang River are mainly presented a natural sources signature, while the 424 anthropogenic heavy metals $(\mathrm{V}, \mathrm{Cr}, \mathrm{Ni}$, and $\mathrm{Cu})$ are greatly impacted by dilution effect. 425 Moreover, the estimation of export flux suggest that the contribution of $\mathrm{V}, \mathrm{Cr}$, Ni, and Mo of 426 Zhujiang River export to the marine system are higher than the world average level. Overall, the 427 water quality is pretty good in the Zhujiang River, but corresponding measures should also be 428 taken to provide a better water resources guarantee for socio-economic development within the 429 whole basin in the future.

430

\section{Acknowledgements}

433

434

435

436

437

438

439

440

441

442

443

444

445

446

447

448

449

450

451

452

453

454

The authors thank Dr. Danyang Zhang from China University of Geosciences (Beijing) for sample analyses.

\section{References}

Bertin G, and Averbeck D. 2006. Cadmium: cellular effects, modifications of biomolecules, modulation of DNA repair and genotoxic consequences (a review). Biochimie 88:1549-1559. https://doi.org/10.1016/j.biochi.2006.10.001

Cameron H, Mata MT, and Riquelme C. 2018. The effect of heavy metals on the viability of Tetraselmis marina AC16-MESO and an evaluation of the potential use of this microalga in bioremediation. PeerJ 6:e5295. 10.7717/peerj.5295

Chen K, Jiao JJ, Huang J, and Huang R. 2007. Multivariate statistical evaluation of trace elements in groundwater in a coastal area in Shenzhen, China. Environmental Pollution 147:771780. https://doi.org/10.1016/j.envpol.2006.09.002

De Miguel E, Iribarren I, Chacón E, Ordoñez A, and Charlesworth S. 2007. Risk-based evaluation of the exposure of children to trace elements in playgrounds in Madrid (Spain). Chemosphere 66:505-513. https://doi.org/10.1016/j.chemosphere.2006.05.065 EPA China, 2006. Environmental Quality Standards for Drinking Water Quality (GB 57492006).

EPA China. 2002. Environmental Quality Standards for Surface Water (GB 3838-2002). EPA US. 2003. National Primary Drinking Water Standards.

EPA US. 2004. Risk Assessment: "Supplemental Guidance for Dermal Risk Assessment".Part E of Risk Assessment Guidance for Superfund, Human Health Evaluation Manual (Volume I) August 16, 2004. 
455 Fang T, Liu G, Zhou C, Sun R, Chen J, and Wu D. 2014. Lead in Chinese coals: distribution, 456 modes of occurrence, and environmental effects. Environmental Geochemistry and Health 457 36:563-581. 10.1007/s10653-013-9581-4

458 Farahat E, and Linderholm HW. 2015. The effect of long-term wastewater irrigation on 459 accumulation and transfer of heavy metals in Cupressus sempervirens leaves and adjacent soils. 460 Science of The Total Environment 512-513:1-7. https://doi.org/10.1016/j.scitotenv.2015.01.032 461 Gaillardet J, Viers J, and Dupré B. 2014. Trace Elements in River Waters. In: Holland HD, and 462 Turekian KK, eds. Treatise on Geochemistry (Second Edition). Oxford: Elsevier, 195-235. 463 Han G, Lv P, Tang Y, and Song Z. 2018. Spatial and temporal variation of H and O isotopic 464 compositions of the Xijiang River system, Southwest China. Isotopes in Environmental and 465 Health Studies 54:137-146. 10.1080/10256016.2017.1368507

466 Iwashita M, and Shimamura T. 2003. Long-term variations in dissolved trace elements in the 467 Sagami River and its tributaries (upstream area), Japan. Science of The Total Environment 468 312:167-179. https://doi.org/10.1016/S0048-9697(03)00251-1

469 Krishna AK, Satyanarayanan M, and Govil PK. 2009. Assessment of heavy metal pollution in water using multivariate statistical techniques in an industrial area: A case study from Patancheru, Medak District, Andhra Pradesh, India. Journal of Hazardous Materials 167:366-373. https://doi.org/10.1016/j.jhazmat.2008.12.131 Li C, Li S-L, Yue F-J, Liu J, Zhong J, Yan Z-F, Zhang R-C, Wang Z-J, and Xu S. 2019. Identification of sources and transformations of nitrate in the Xijiang River using nitrate isotopes and Bayesian model. Science of The Total Environment 646:801-810. https://doi.org/10.1016/j.scitotenv.2018.07.345

478 Li S, Li J, and Zhang Q. 2011. Water quality assessment in the rivers along the water conveyance system of the Middle Route of the South to North Water Transfer Project (China) using multivariate statistical techniques and receptor modeling. Journal of Hazardous Materials 195:306-317. https://doi.org/10.1016/j.jhazmat.2011.08.043 Li S, Xu Z, Cheng X, and Zhang Q. 2008. Dissolved trace elements and heavy metals in the Danjiangkou Reservoir, China. Environmental Geology 55:977-983. 10.1007/s00254-007-10475 Li S, and Zhang Q. 2010. Spatial characterization of dissolved trace elements and heavy metals in the upper Han River (China) using multivariate statistical techniques. Journal of Hazardous Materials 176:579-588. https://doi.org/10.1016/j.jhazmat.2009.11.069 Li X, Wai OWH, Li YS, Coles BJ, Ramsey MH, and Thornton I. 2000. Heavy metal distribution in sediment profiles of the Pearl River estuary, South China. Applied Geochemistry 15:567-581. https://doi.org/10.1016/S0883-2927(99)00072-4 agricultural soils along Jishui River in non-ferrous metal mine area in Jiangxi Province, China. Journal of Geochemical Exploration 132:156-163. https://doi.org/10.1016/j.gexplo.2013.06.017 
493 Liu J, Li S-L, Chen J-B, Zhong J, Yue F-J, Lang Y, and Ding H. 2017. Temporal transport of 494 major and trace elements in the upper reaches of the Xijiang River, SW China. Environmental 495 Earth Sciences 76:299. 10.1007/s12665-017-6625-6

496 Loska K, and Wiechuła D. 2003. Application of principal component analysis for the estimation 497 of source of heavy metal contamination in surface sediments from the Rybnik Reservoir.

498 Chemosphere 51:723-733. https://doi.org/10.1016/S0045-6535(03)00187-5

499 Meng Q, Zhang J, Zhang Z, and Wu T. 2016. Geochemistry of dissolved trace elements and 500 heavy metals in the Dan River Drainage (China): distribution, sources, and water quality 501 assessment. Environmental Science \& Pollution Research 23:8091-8103.

502 https://doi.org/10.1007/s11356-016-6074-x

503 Niu HY, Deng WJ, Wu QH, and Chen XG. 2009. Potential toxic risk of heavy metals from 504 sediment of the Pearl River in South China. Journal of Environmental Sciences 21:1053-1058. 505 10.1016/s1001-0742(08)62381-5

506 Olías M, Nieto JM, Sarmiento AM, Cerón JC, and Cánovas CR. 2004. Seasonal water quality 507 variations in a river affected by acid mine drainage: the Odiel River (South West Spain). Science 508 of The Total Environment 333:267-281. https://doi.org/10.1016/j.scitotenv.2004.05.012 509 Ouyang TP, Kuang YQ, Tan JJ, Guo GZ, and Li-Song GU. 2004. Spatial distribution of trace 510 element in rivers in the Pearl River Delta Economic Zone, in Chinese. Hydrogeology \& 511 Engineering Geology 31:66-69.

512 Pekey H, Karakaş D, and Bakog `u M. 2004. Source apportionment of trace metals in surface 513 waters of a polluted stream using multivariate statistical analyses. Marine Pollution Bulletin 514 49:809-818. https://doi.org/10.1016/j.marpolbul.2004.06.029

515 Thévenot DR, Moilleron R, Lestel L, Gromaire M-C, Rocher V, Cambier P, Bonté P, Colin J-L, 516 de Pontevès $\mathrm{C}$, and Meybeck M. 2007. Critical budget of metal sources and pathways in the 517 Seine River basin (1994-2003) for $\mathrm{Cd}, \mathrm{Cr}, \mathrm{Cu}, \mathrm{Hg}, \mathrm{Ni}, \mathrm{Pb}$ and $\mathrm{Zn}$. Science of The Total 518 Environment 375:180-203. https://doi.org/10.1016/j.scitotenv.2006.12.008

519 Tripathee L, Kang S, Sharma CM, Rupakheti D, Paudyal R, Huang J, and Sillanpää M. 2016. 520 Preliminary Health Risk Assessment of Potentially Toxic Metals in Surface Water of the 521 Himalayan Rivers, Nepal. Bulletin of Environmental Contamination \& Toxicology 97:855-862.

522 https://doi.org/10.1007/s00128-016-1945-x

523 Vyskocil A, and Viau C. 1999. Assessment of molybdenum toxicity in humans. Journal of 524 Applied Toxicology 19:185-192. 10.1002/(sici)1099-1263(199905/06)19:3<185::aid525 jat555>3.0.co;2-z

526 Wang J, Liu G, Liu H, and Lam PK. 2017. Multivariate statistical evaluation of dissolved trace 527 elements and a water quality assessment in the middle reaches of Huaihe River, Anhui, China. 528 Science of The Total Environment 583:421-431. https://doi.org/10.1016/j.scitotenv.2017.01.088 529 WHO. 2006. Guidelines for Drinking-water Quality. 3rd ed. Geneva: Word Health Organization. 530 Wilbers G-J, Becker M, Nga LT, Sebesvari Z, and Renaud FG. 2014. Spatial and temporal 531 variability of surface water pollution in the Mekong Delta, Vietnam. Science of The Total 532 Environment 485-486:653-665. https://doi.org/10.1016/j.scitotenv.2014.03.049 
533 Wu B, Zhao DY, Jia HY, Zhang Y, Zhang XX, and Cheng SP. 2009. Preliminary Risk

534 Assessment of Trace Metal Pollution in Surface Water from Yangtze River in Nanjing Section,

535 China. Bulletin of Environmental Contamination and Toxicology 82:405-409. 10.1007/s00128-

$536 \quad 008-9497-3$

537 Xiao J, Jin Z, and Wang J. 2014. Geochemistry of trace elements and water quality assessment of 538 natural water within the Tarim River Basin in the extreme arid region, NW China. Journal of

539 Geochemical Exploration 136:118-126. https://doi.org/10.1016/j.gexplo.2013.10.013

$540 \mathrm{Xu} \mathrm{Z}$, and Han G. 2009. Rare earth elements (REE) of dissolved and suspended loads in the

541 Xijiang River, South China. Applied Geochemistry 24:1803-1816.

542 https://doi.org/10.1016/j.apgeochem.2009.06.001

543 Zaric NM, Deljanin I, Ilijević K, Stanisavljević L, Ristić M, and Gržetić I. 2018. Assessment of

544 spatial and temporal variations in trace element concentrations using honeybees (Apis mellifera)

545 as bioindicators. PeerJ 6:e5197. 10.7717/peerj.5197

546 Zhang J, Yan Q, Jiang J, Song B, and Chen T. 2018. Distribution and risk assessment of heavy

547 metals in river surface sediments of middle reach of Xijiang River basin, China. Human and

548 Ecological Risk Assessment 24:347-361. 10.1080/10807039.2017.1383850

549 Zhang LC, and Zhou KH. 1992. Backgroud values of trace elements in the source area of the

550 Yangtze river. Science of The Total Environment 125:391-404. https://doi.org/10.1016/0048-

551 9697(92)90403-F

552 Zhang W, Feng H, Chang J, Qu J, Xie H, and Yu L. 2009. Heavy metal contamination in surface

553 sediments of Yangtze River intertidal zone: An assessment from different indexes.

554 Environmental Pollution 157:1533-1543. https://doi.org/10.1016/j.envpol.2009.01.007

555 Zhen G, Li Y, Tong Y, Yang L, Zhu Y, and Zhang W. 2016. Temporal variation and regional

556 transfer of heavy metals in the Pearl (Zhujiang) River, China. Environmental Science and

557 Pollution Research 23:8410-8420. 10.1007/s11356-016-6077-7 


\section{Figure 1 (on next page)}

Sketch map showing the lithology and sampling locations of the Zhujiang River system.

The base map is from Han et al. 2018. 


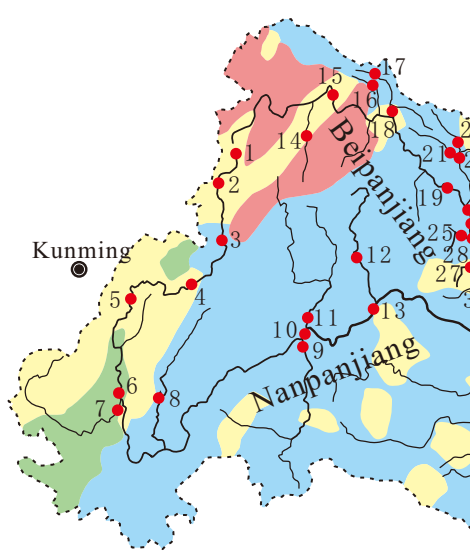

\section{Legend}

Sedimentary rocks Carbonates

Metamorphic rocks Magmatic rocks

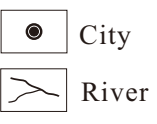

Boundries

- Sampling point 


\section{Figure 2 (on next page)}

Spatial-temporal variations of 10 heavy metals in 25 sampling sites along the main stream from Zhujiang River.

NPR, Nanpanjiang River; HSR, Hongshuihe River; QJR, Qianjiang River; XUJ, Xunjiang River; XJR, Xijiang River. The vertical black dash line divides the different river reaches. 


\section{Figure 3 (on next page)}

Distribution of 10 heavy metals in tributaries from Zhujiang River.

T-NPR, tributaries of Nanpanjiang River; T-BPR, tributaries of Beipanjiang River; T-HSR, tributaries of Hongshuihe River; T-QJR, tributaries of Qianjiang River; T-XUJ, tributaries of Xunjiang River; T-XJR, tributaries of Xijiang River. 
Figure 4 (on next page)

3D plot of scores obtained from PCA results for dissolved heavy metals along the main channel of Zhujiang River. 


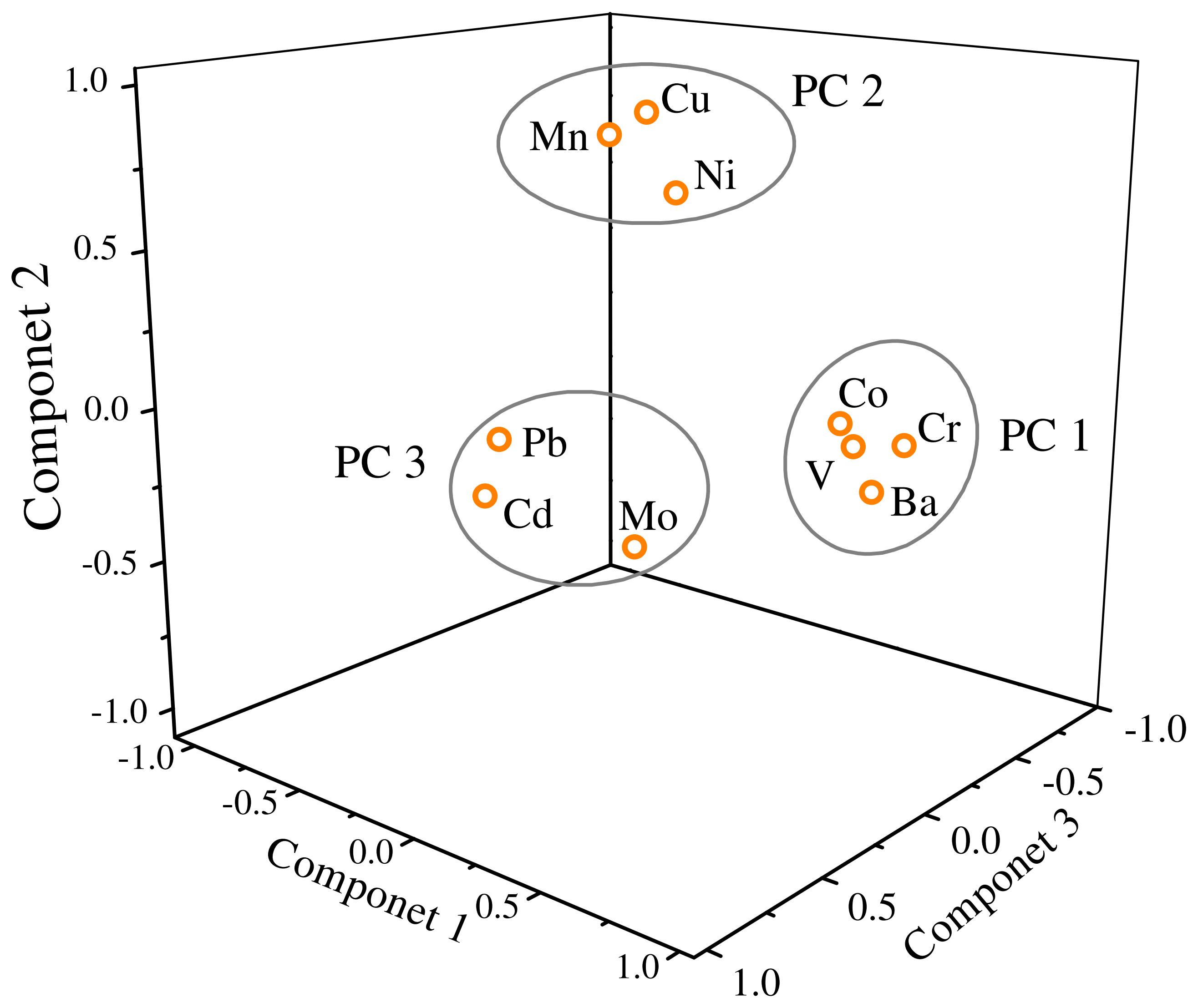




\section{Table $\mathbf{1}$ (on next page)}

Concentrations of dissolved heavy metals $\left(\mu \mathrm{g} \mathrm{L}^{-1}\right), \mathrm{pH}$, electric conductivity $\left(\mu \mathrm{cm}^{-1}\right)$, dissolved oxygen $\left(\mathrm{mg} \mathrm{L}^{-1}\right)$, and temperature $\left({ }^{\circ} \mathrm{C}\right)$ in the Zhujiang River, China. 


\begin{tabular}{|c|c|c|c|c|c|c|c|c|c|c|c|c|c|c|c|c|}
\hline & \multicolumn{6}{|c|}{ Low flow season } & \multicolumn{6}{|c|}{ High flow season } & \multicolumn{3}{|c|}{ Drinking water guidelines } & \multirow{2}{*}{$\begin{array}{l}\text { Source area of } \\
\text { Yangtze River }\end{array}$} \\
\hline & Min & Max & Mean & $\mathrm{SD}$ & Median & $\mathrm{K}-\mathrm{S}$ test $\mathrm{t}^{\mathrm{a}}$ & Min & Max & Mean & $\mathrm{SD}$ & Median & $\mathrm{K}-\mathrm{S}$ test $\mathrm{t}^{\mathrm{a}}$ & China $^{\mathrm{b}}$ & $\mathrm{WHO}^{\mathrm{c}}$ & US EPA $^{\mathrm{d}}$ & \\
\hline $\mathrm{V}$ & 1.51 & 3.00 & 2.11 & 0.32 & 2.13 & 0.758 & 1.96 & 3.53 & 2.66 & 0.36 & 2.59 & 0.469 & & & & 0.23 \\
\hline $\mathrm{Cr}$ & 2.51 & 12.00 & 6.78 & 1.79 & 6.85 & 0.864 & 1.82 & 14.96 & 7.45 & 2.84 & 7.52 & 0.709 & 50 & 50 & 100 & 0.26 \\
\hline $\mathrm{Mn}$ & 0.15 & 267.33 & 8.47 & 39.99 & 0.45 & 0.000 & 0.11 & 134.49 & 5.84 & 17.95 & 0.40 & 0.000 & 100 & 400 & & 2.53 \\
\hline Co & 0.03 & 1.57 & 0.15 & 0.18 & 0.11 & 0.000 & 0.04 & 0.51 & 0.12 & 0.08 & 0.11 & 0.001 & 1000 & & & 0.24 \\
\hline $\mathrm{Ni}$ & 0.47 & 37.35 & 4.10 & 6.33 & 2.39 & 0.000 & 0.47 & 49.03 & 4.43 & 7.50 & 2.08 & 0.000 & 20 & 70 & & 0.18 \\
\hline $\mathrm{Cu}$ & 0.33 & 115.73 & 3.93 & 13.83 & 0.90 & 0.000 & 0.24 & 136.80 & 8.24 & 23.34 & 0.77 & 0.000 & 1000 & 2000 & 1300 & 0.63 \\
\hline Mo & 0.11 & 95.75 & 1.89 & 10.58 & 0.63 & 0.000 & 0.13 & 0.96 & 0.49 & 0.21 & 0.44 & 0.134 & 70 & & & 0.72 \\
\hline $\mathrm{Cd}$ & 0.02 & 2.09 & 0.09 & 0.23 & 0.04 & 0.000 & 0.02 & 1.36 & 0.06 & 0.15 & 0.03 & 0.000 & 5 & 3 & 5 & 0.02 \\
\hline $\mathrm{Ba}$ & 7.99 & 46.79 & 16.59 & 7.12 & 14.72 & 0.000 & 4.00 & 48.40 & 14.22 & 7.59 & 12.50 & 0.001 & 700 & 700 & 2000 & \\
\hline $\mathrm{Pb}$ & 0.03 & 0.60 & 0.07 & 0.07 & 0.06 & 0.000 & 0.02 & 0.45 & 0.06 & 0.06 & 0.04 & 0.000 & 10 & 10 & 15 & 0.76 \\
\hline $\mathrm{pH}$ & 7.0 & 8.8 & 7.9 & 0.4 & 7.9 & 0.546 & 6.4 & 8.4 & 7.7 & 0.4 & 7.7 & 0.659 & $6.5-8.5$ & & & \\
\hline EC & 76.0 & 602.0 & 354.6 & 123.3 & 353.0 & 0.606 & 90.0 & 533.0 & 307.7 & 114.2 & 319.0 & 0.627 & & & & \\
\hline DO & 6.1 & 11.8 & 8.7 & 1.0 & 8.8 & 0.976 & 4.9 & 12.4 & 7.5 & 1.3 & 7.3 & 0.316 & & & & \\
\hline $\mathrm{T}$ & 10.2 & 26.6 & 16.4 & 2.7 & 16.8 & 0.096 & 18.0 & 36.0 & 26.5 & 4.2 & 27.3 & 0.425 & & & & \\
\hline
\end{tabular}

${ }^{a}$ Kolmogorov-Smirnov test.

${ }^{\mathrm{b}}$ Chinese drinking water standards (GB 5749-2006).

${ }^{c}$ WHO (2006) drinking water guidelines.

${ }^{d}$ US EPA (2003) drinking water standards.

e Zhang and Zhou (1992) 


\section{Table 2 (on next page)}

Pearson correlation matrix of heavy metals and physicochemical parameters $(\mathrm{pH}, \mathrm{EC}$, DO, and T) in the Zhujiang River, China. 


\begin{tabular}{|c|c|c|c|c|c|c|c|c|c|c|c|c|c|c|}
\hline & V & $\mathrm{Cr}$ & $\mathrm{Mn}$ & Co & $\mathrm{Ni}$ & $\mathrm{Cu}$ & Mo & $\mathrm{Cd}$ & $\mathrm{Ba}$ & $\mathrm{Pb}$ & $\mathrm{pH}$ & $\mathrm{EC}$ & DO & $\mathrm{T}$ \\
\hline V & 1 & -0.176 & -0.144 & $-0.254^{*}$ & 0.126 & -0.146 & 0.085 & -0.069 & 0.124 & -0.012 & $-0.462^{* * *}$ & -0.187 & $-0.625^{* * *}$ & $0.316^{* * *}$ \\
\hline $\mathrm{Cr}$ & -0.017 & 1 & $-0.241^{*}$ & $0.477^{* * *}$ & $0.308^{* *}$ & 0.081 & 0.209 & -0.094 & $0.421^{* *}$ & 0.006 & $0.563^{* * *}$ & $0.852^{* * *}$ & 0.117 & $-0.552^{\text {** }}$ \\
\hline $\mathrm{Mn}$ & 0.021 & $-0.290^{* *}$ & 1 & $0.520^{* *}$ & -0.059 & 0.077 & 0.215 & $0.227^{*}$ & -0.119 & 0.079 & -0.129 & -0.081 & -0.028 & -0.076 \\
\hline Co & -0.177 & 0.014 & $0.591^{* *}$ & 1 & 0.122 & 0.046 & 0.215 & 0.040 & $0.252^{*}$ & 0.006 & $0.280^{*}$ & $0.481^{* *}$ & 0.082 & $-0.372^{* *}$ \\
\hline $\mathrm{Ni}$ & -0.050 & -0.148 & $0.312^{* *}$ & 0.041 & 1 & $0.538^{* *}$ & 0.178 & -0.040 & $0.303^{* *}$ & 0.012 & $0.235^{\star}$ & $0.323^{* *}$ & 0.029 & $-0.316^{* *}$ \\
\hline $\mathrm{Cu}$ & -0.025 & -0.176 & -0.005 & -0.009 & $0.650^{* *}$ & 1 & 0.103 & -0.055 & 0.086 & 0.050 & 0.206 & 0.182 & 0.082 & $-0.328^{* *}$ \\
\hline Mo & 0.034 & -0.172 & -0.028 & -0.063 & -0.048 & 0.017 & 1 & 0.079 & $0.274^{*}$ & -0.006 & $0.493^{* *}$ & $0.498^{* *}$ & $0.243^{*}$ & -0.190 \\
\hline $\mathrm{Cd}$ & 0.143 & -0.159 & -0.028 & -0.036 & -0.029 & -0.025 & 0.114 & 1 & -0.117 & $0.279^{*}$ & 0.018 & 0.084 & -0.001 & 0.075 \\
\hline $\mathrm{Ba}$ & $0.287^{* *}$ & $0.219^{*}$ & 0.059 & -0.011 & 0.155 & 0.021 & -0.016 & 0.008 & 1 & -0.035 & 0.216 & $0.446^{* *}$ & 0.001 & -0.216 \\
\hline $\mathrm{Pb}$ & 0.008 & -0.130 & $0.673^{* *}$ & $0.284^{*}$ & -0.001 & -0.008 & -0.036 & -0.044 & -0.050 & 1 & 0.049 & 0.018 & 0.173 & 0.082 \\
\hline $\mathrm{pH}$ & $-0.494^{* *}$ & $0.594^{* *}$ & $-0.241^{*}$ & 0.086 & $-0.280^{*}$ & $-0.319^{* *}$ & -0.032 & -0.148 & 0.123 & -0.089 & 1 & $0.702^{* *}$ & $0.668^{* * *}$ & $-0.400^{* *}$ \\
\hline EC & $-0.360^{* *}$ & $0.773^{* *}$ & $-0.237^{*}$ & 0.202 & -0.100 & -0.130 & -0.154 & -0.084 & 0.203 & -0.111 & $0.771^{* *}$ & 1 & 0.215 & $-0.660^{\text {** }}$ \\
\hline DO & -0.125 & -0.186 & 0.008 & 0.070 & -0.015 & -0.065 & 0.166 & 0.071 & -0.013 & -0.010 & 0.068 & 0.003 & 1 & -0.040 \\
\hline $\mathrm{T}$ & 0.202 & $-0.326^{* *}$ & 0.053 & $-0.235^{*}$ & 0.136 & 0.154 & 0.016 & -0.029 & -0.147 & 0.057 & $-0.567^{* *}$ & $-0.532^{* *}$ & -0.108 & 1 \\
\hline
\end{tabular}

*. Correlation is significant at the 0.05 level (2-tailed).

**. Correlation is significant at the 0.01 level (2-tailed).

Bold italics: correlation coefficients in high flow season; Normal font: correlation coefficients in low flow season. 


\section{Table 3(on next page)}

Varimax rotated component matrix for dissolved heavy metals along the main channel of Zhujiang River (the significance of KMO and Bartlett's sphericity test is $<0.001$ ). 


\begin{tabular}{lllll}
\hline Eigenvalues & 2.26 & 2.09 & 1.82 & Communalities \\
Variance (\%) & 22.59 & 20.91 & 18.23 & \\
Cumulative (\%) & 22.59 & 43.50 & 61.74 & \\
Variable & PC 1 & PC 2 & PC 3 & \\
\hline $\mathrm{V}$ & $\mathbf{0 . 1 8}$ & -0.22 & -0.73 & 0.60 \\
$\mathrm{Cr}$ & $\mathbf{0 . 8 5}$ & -0.02 & -0.12 & 0.74 \\
$\mathrm{Mn}$ & -0.20 & $\mathbf{0 . 8 1}$ & -0.01 & 0.71 \\
$\mathrm{Co}$ & $\mathbf{0 . 8 4}$ & 0.04 & 0.12 & 0.72 \\
$\mathrm{Ni}$ & 0.10 & $\mathbf{0 . 6 7}$ & 0.03 & 0.46 \\
$\mathrm{Cu}$ & -0.08 & $\mathbf{0 . 8 9}$ & -0.04 & 0.80 \\
$\mathrm{Mo}$ & 0.32 & -0.29 & $\mathbf{0 . 4 7}$ & 0.40 \\
$\mathrm{Cd}$ & -0.03 & -0.14 & $\mathbf{0 . 7 1}$ & 0.53 \\
$\mathrm{Ba}$ & $\mathbf{0 . 7 9}$ & -0.15 & -0.04 & 0.66 \\
$\mathrm{~Pb}$ & 0.05 & 0.05 & $\mathbf{0 . 7 4}$ & 0.55 \\
\hline
\end{tabular}

Extraction method: Principal component analysis.

Rotation method: Varimax with Kaiser normalization. 


\section{Table 4(on next page)}

Weights for the ten dissolved heavy metals in the water samples from the Zhujiang River. 


\begin{tabular}{|c|c|c|c|c|c|c|}
\hline $\mathrm{PC}$ & Eigenvalue & Relative eigenvalue & Variable & Loading value & $\begin{array}{l}\text { Relative loading } \\
\text { value on same PC }\end{array}$ & $\begin{array}{l}\text { Weight (relative eigenvalue } \\
\times \text { relative loading value) }\end{array}$ \\
\hline \multirow[t]{5}{*}{1} & 2.26 & 0.37 & $\mathrm{~V}$ & 0.18 & 0.07 & 0.02 \\
\hline & & & $\mathrm{Cr}$ & 0.85 & 0.32 & 0.12 \\
\hline & & & $\mathrm{Co}$ & 0.84 & 0.32 & 0.12 \\
\hline & & & $\mathrm{Ba}$ & 0.79 & 0.30 & 0.11 \\
\hline & & & Total & 2.66 & 1.00 & \\
\hline \multirow[t]{4}{*}{2} & 2.09 & 0.34 & $\mathrm{Mn}$ & 0.81 & 0.34 & 0.12 \\
\hline & & & $\mathrm{Ni}$ & 0.67 & 0.28 & 0.10 \\
\hline & & & $\mathrm{Cu}$ & 0.89 & 0.37 & 0.13 \\
\hline & & & Total & 2.38 & 1.00 & \\
\hline \multirow[t]{4}{*}{3} & 1.82 & 0.30 & Mo & 0.47 & 0.24 & 0.07 \\
\hline & 6.17 & & $\mathrm{Cd}$ & 0.71 & 0.37 & 0.11 \\
\hline & & & $\mathrm{Pb}$ & 0.74 & 0.38 & 0.11 \\
\hline & & & Total & 1.91 & 1.00 & 1.00 \\
\hline
\end{tabular}




\section{Table 5 (on next page)}

Hazard quotient (HQ), dermal permeability coefficient $\left(\mathrm{K}_{\mathrm{p}}\right)$, and reference dose (RfD) for dissolved heavy metals in the Zhujiang River. 


\begin{tabular}{|c|c|c|c|c|c|c|c|c|c|}
\hline & \multicolumn{2}{|l|}{$\mathrm{HQ}_{\text {ingestion }}$} & \multicolumn{2}{|l|}{$\mathrm{HQ}_{\text {dermal }}$} & \multicolumn{2}{|l|}{$\mathrm{HI}=\Sigma \mathrm{HQs}$} & \multirow{2}{*}{$\begin{array}{l}\mathrm{K}_{\mathrm{p}}^{\mathrm{a}} \\
\mathrm{cm} \mathrm{h}^{-1}\end{array}$} & \multirow{2}{*}{$\begin{array}{l}\operatorname{RfD}_{\text {ingestion }}{ }^{\mathrm{b}, \mathrm{c}} \\
\mu \mathrm{g} \mathrm{kg}^{-1} \text { day }^{-1}\end{array}$} & \multirow{2}{*}{$\begin{array}{l}\mathrm{RfD}_{\text {dermal }}^{\mathrm{b}, \mathrm{c}} \\
\mu \mathrm{g} \mathrm{kg}^{-1} \mathrm{day}^{-1}\end{array}$} \\
\hline & Adult & Children & Adult & Children & Adult & Children & & & \\
\hline \multicolumn{10}{|c|}{ low flow season } \\
\hline $\mathrm{V}$ & $5.83 \times 10^{-2}$ & $8.70 \times 10^{-2}$ & $6.08 \times 10^{-2}$ & $1.80 \times 10^{-1}$ & $1.19 \times 10^{-1}$ & $2.67 \times 10^{-1}$ & $2.00 \times 10^{-3}$ & 1 & 0.01 \\
\hline $\mathrm{Cr}$ & $6.26 \times 10^{-2}$ & $9.34 \times 10^{-2}$ & $1.31 \times 10^{-2}$ & $3.85 \times 10^{-2}$ & $7.56 \times 10^{-2}$ & $1.32 \times 10^{-1}$ & $1.00 \times 10^{-3}$ & 3 & 0.075 \\
\hline $\mathrm{Mn}$ & $5.10 \times 10^{-4}$ & $7.62 \times 10^{-4}$ & $6.66 \times 10^{-5}$ & $1.96 \times 10^{-4}$ & $5.77 \times 10^{-4}$ & $9.58 \times 10^{-4}$ & $1.00 \times 10^{-3}$ & 24 & 0.96 \\
\hline Co & $1.02 \times 10^{-2}$ & $1.53 \times 10^{-2}$ & $1.07 \times 10^{-4}$ & $3.15 \times 10^{-4}$ & $1.03 \times 10^{-2}$ & $1.56 \times 10^{-2}$ & $4.00 \times 10^{-4}$ & 0.3 & 0.06 \\
\hline $\mathrm{Ni}$ & $3.27 \times 10^{-3}$ & $4.89 \times 10^{-3}$ & $8.55 \times 10^{-5}$ & $2.52 \times 10^{-4}$ & $3.36 \times 10^{-3}$ & $5.14 \times 10^{-3}$ & $2.00 \times 10^{-4}$ & 20 & 0.8 \\
\hline $\mathrm{Cu}$ & $6.16 \times 10^{-4}$ & $9.19 \times 10^{-4}$ & $1.61 \times 10^{-5}$ & $4.74 \times 10^{-5}$ & $6.32 \times 10^{-4}$ & $9.67 \times 10^{-4}$ & $1.00 \times 10^{-3}$ & 40 & 8 \\
\hline Mo & $3.45 \times 10^{-3}$ & $5.15 \times 10^{-3}$ & $9.47 \times 10^{-5}$ & $2.79 \times 10^{-4}$ & $3.54 \times 10^{-3}$ & $5.43 \times 10^{-3}$ & $2.00 \times 10^{-3}$ & 5 & 1.9 \\
\hline $\mathrm{Cd}$ & $2.40 \times 10^{-3}$ & $3.58 \times 10^{-3}$ & $2.51 \times 10^{-4}$ & $7.39 \times 10^{-4}$ & $2.65 \times 10^{-3}$ & $4.32 \times 10^{-3}$ & $1.00 \times 10^{-3}$ & 0.5 & 0.025 \\
\hline $\mathrm{Ba}$ & $2.02 \times 10^{-3}$ & $3.01 \times 10^{-3}$ & $1.50 \times 10^{-4}$ & $4.44 \times 10^{-4}$ & $2.17 \times 10^{-3}$ & $3.46 \times 10^{-3}$ & $1.00 \times 10^{-3}$ & 200 & 14 \\
\hline $\mathrm{Pb}$ & $1.10 \times 10^{-3}$ & $1.65 \times 10^{-3}$ & $1.92 \times 10^{-6}$ & $5.66 \times 10^{-6}$ & $1.10 \times 10^{-3}$ & $1.65 \times 10^{-3}$ & $1.00 \times 10^{-4}$ & 1.4 & 0.42 \\
\hline \multicolumn{10}{|c|}{ high flow season } \\
\hline V & $7.09 \times 10^{-2}$ & $1.06 \times 10^{-1}$ & $7.40 \times 10^{-2}$ & $2.18 \times 10^{-1}$ & $1.45 \times 10^{-1}$ & $3.24 \times 10^{-1}$ & $2.00 \times 10^{-3}$ & 1 & 0.01 \\
\hline $\mathrm{Cr}$ & $6.87 \times 10^{-2}$ & $1.03 \times 10^{-1}$ & $1.43 \times 10^{-2}$ & $4.23 \times 10^{-2}$ & $8.30 \times 10^{-2}$ & $1.45 \times 10^{-1}$ & $1.00 \times 10^{-3}$ & 3 & 0.075 \\
\hline $\mathrm{Mn}$ & $4.54 \times 10^{-4}$ & $6.78 \times 10^{-4}$ & $5.93 \times 10^{-5}$ & $1.75 \times 10^{-4}$ & $5.13 \times 10^{-4}$ & $8.53 \times 10^{-4}$ & $1.00 \times 10^{-3}$ & 24 & 0.96 \\
\hline Co & $9.86 \times 10^{-3}$ & $1.47 \times 10^{-2}$ & $1.03 \times 10^{-4}$ & $3.04 \times 10^{-4}$ & $9.96 \times 10^{-3}$ & $1.50 \times 10^{-2}$ & $4.00 \times 10^{-4}$ & 0.3 & 0.06 \\
\hline $\mathrm{Ni}$ & $2.84 \times 10^{-3}$ & $4.25 \times 10^{-3}$ & $7.43 \times 10^{-5}$ & $2.19 \times 10^{-4}$ & $2.92 \times 10^{-3}$ & $4.47 \times 10^{-3}$ & $2.00 \times 10^{-4}$ & 20 & 0.8 \\
\hline $\mathrm{Cu}$ & $5.27 \times 10^{-4}$ & $7.87 \times 10^{-4}$ & $1.38 \times 10^{-5}$ & $4.06 \times 10^{-5}$ & $5.41 \times 10^{-4}$ & $8.28 \times 10^{-4}$ & $1.00 \times 10^{-3}$ & 40 & 8 \\
\hline Mo & $2.41 \times 10^{-3}$ & $3.60 \times 10^{-3}$ & $6.63 \times 10^{-5}$ & $1.95 \times 10^{-4}$ & $2.48 \times 10^{-3}$ & $3.80 \times 10^{-3}$ & $2.00 \times 10^{-3}$ & 5 & 1.9 \\
\hline $\mathrm{Cd}$ & $1.80 \times 10^{-3}$ & $2.69 \times 10^{-3}$ & $1.88 \times 10^{-4}$ & $5.55 \times 10^{-4}$ & $1.99 \times 10^{-3}$ & $3.24 \times 10^{-3}$ & $1.00 \times 10^{-3}$ & 0.5 & 0.025 \\
\hline $\mathrm{Ba}$ & $1.71 \times 10^{-3}$ & $2.56 \times 10^{-3}$ & $1.28 \times 10^{-4}$ & $3.77 \times 10^{-4}$ & $1.84 \times 10^{-3}$ & $2.93 \times 10^{-3}$ & $1.00 \times 10^{-3}$ & 200 & 14 \\
\hline $\mathrm{Pb}$ & $8.50 \times 10^{-4}$ & $1.27 \times 10^{-3}$ & $1.48 \times 10^{-6}$ & $4.37 \times 10^{-6}$ & $8.52 \times 10^{-4}$ & $1.27 \times 10^{-3}$ & $1.00 \times 10^{-4}$ & 1.4 & 0.42 \\
\hline \multicolumn{10}{|c|}{ low flow season, calculated by the maximal concentrations } \\
\hline $\mathrm{Mn}$ & $3.05 \times 10^{-1}$ & $4.56 \times 10^{-1}$ & $3.98 \times 10^{-2}$ & $1.17 \times 10^{-1}$ & $3.45 \times 10^{-1}$ & $5.73 \times 10^{-1}$ & $1.00 \times 10^{-3}$ & 24 & 0.96 \\
\hline Mo & $5.25 \times 10^{-1}$ & $7.84 \times 10^{-1}$ & $1.44 \times 10^{-2}$ & $4.25 \times 10^{-2}$ & $5.39 \times 10^{-1}$ & $8.26 \times 10^{-1}$ & $2.00 \times 10^{-3}$ & 5 & 1.9 \\
\hline
\end{tabular}

${ }^{a}$ US EPA (2004)

b Wang et al.(2017)

${ }^{c}$ Wu et al.(2009) 
Table 6 (on next page)

Export fluxes estimation of heavy metals in two seasons ( $t$ ), annual export flux of Zhujiang River ( $\left.\mathrm{t} \mathrm{r}^{-1}\right)$ to the South China Sea, and the world riverine flux $\left(\mathrm{kt} \mathrm{yr}^{-1}\right)$. 


\begin{tabular}{lllllllllll}
\hline Flux & $\mathrm{V}$ & $\mathrm{Cr}$ & $\mathrm{Mn}$ & $\mathrm{Co}$ & $\mathrm{Ni}$ & $\mathrm{Cu}$ & $\mathrm{Mo}$ & $\mathrm{Cd}$ & $\mathrm{Ba}$ & $\mathrm{Pb}$ \\
\hline Low flow season (This study) & 148.3 & 380.0 & 79.5 & 5.7 & 210.1 & 65.1 & 36.1 & 2.3 & 968.1 & 3.1 \\
High flow season (This study) & 587.3 & 1181.1 & 26.4 & 13.8 & 288.1 & 108.9 & 82.8 & 9.1 & 2745.4 & 5.4 \\
Zhujiang River (This study) & 735.6 & 1561.1 & 105.9 & 19.5 & 498.2 & 173.9 & 118.9 & 11.3 & 3713.5 & 8.6 \\
Zhujiang River (2002) & 257.3 & 2860.9 & 11178.5 & 35.3 & 1904.8 & 1455.6 & 339.3 & 12.6 & 6007.6 & 99.0 \\
World riverine flux & 27.0 & 26.0 & 1270.0 & 5.5 & 30.0 & 55.0 & 16.0 & 3.0 & 860.2 & 3.0 \\
\hline
\end{tabular}

${ }^{a}$ The data for flux calculation is from Ouyang et al.(2004)

${ }^{\mathrm{b}}$ Gaillardet et al., 2014 